\title{
PF573,228 inhibits vascular tumor cell growth, migration as well as angiogenesis, induces apoptosis and abrogates PRAS40 and S6RP phosphorylation
}

\author{
PEACE MABETA \\ Angiogenesis Laboratory \\ Department of Anatomy \\ and Physiology \\ University of Pretoria, Private Bag X04 \\ Tshwane, 0110, South Africa
}

Accepted January 11, 2016

Published online May 3, 2016

\begin{abstract}
PF573,228 is a compound that targets focal adhesion kinase (FAK), a non-receptor protein kinase, which is over-expressed in various tumors. The aim of this study was to evaluate the effects of PF573,228 on the cells derived from mouse vascular tumors, namely, endothelioma cells.

The treatment of endothelioma cells with PF573,228 reduced their growth with an $I C_{50}$ of approximately $4.6 \mu \mathrm{mol} \mathrm{L}{ }^{-1}$ and inhibited cell migration with an $I C_{50}$ of about $0.01 \mu \mathrm{mol} \mathrm{L} \mathrm{L}^{-1}$. Microscopic studies revealed morphological attributes of apoptosis. These observations were confirmed by ELISA, which showed increased caspase- 3 activity. PF573,228 also inhibited angiogenesis in a dose-dependent manner, with an $I C_{50}$ of approximately $3.7 \mu \mathrm{mol} \mathrm{L}{ }^{-1}$, and abrogated the phosphorylation of cell survival proteins, proline-rich Akt substrate (PRAS40) and S6 ribosomal protein (S6RP). Array data further revealed that PF573,228 induced caspase-3 activation, thus promoting apoptosis. Since all the processes inhibited by PF573,228 provide important support to tumor survival and progression, the drug may have a potential role in the treatment of vascular tumors.
\end{abstract}

Keywords: PF573,228, focal adhesion kinase, endothelioma, apoptosis, angiogenesis

PF573,228 is a small molecule that targets the ATP-binding site of focal adhesion kinase (FAK) and effectively blocks its catalytic activity in a variety of cell lines (1). Focal adhesion kinase is a cytoplasmic tyrosine kinase localized in areas of cell surface that interact with neighboring cells and with the extracellular matrix (ECM) $(1,2)$. It plays an important role under various physiological processes that include cell survival and growth, as well as integrin-mediated cell migration $(1,3)$. However, FAK also promotes these cellular processes in pathological conditions such as tumor development and progression $(4,5)$.

In vitro, vascular tumor cells have been reported to exhibit altered FAK expression when compared to normal human dermal microvascular cells, while in patients, FAK

\footnotetext{
*Correspondence; e-mail: peace.mabeta@up.ac.za
} 
seems to promote tumor cell invasion and metastasis (6, 7). Activated FAK leads to activation of protein kinase $\mathrm{B}(\mathrm{PKB})$, thus promoting cell survival and inhibiting apoptosis $(8,9)$. Impaired PKB signaling has been associated with the development of vascular tumors (endotheliomas) in mice (10). The proangiogenic factor, vascular endothelial growth factor (VEGF), which is implicated in the pathogenesis of vascular tumors like infantile hemangiomas (IH), uses the PKB signaling pathway to promote cell growth, migration and angiogenesis (11).

Treatment of IH and other endothelial neoplasms such as hemangioendotheliomas continues to pose a challenge, largely due to the rudimentary knowledge of their pathophysiology. The endothelioma cells used in this study were derived from murine vascular tumors previously employed as a model to study IH and hemangioendotheliomas $(10,12$, 13).

The aim of the study was to investigate the effects of blocking FAK in endothelioma cell growth, apoptosis and migration in vitro as well as on angiogenesis ex vivo and on intracellular signaling molecules that regulate cell survival and death.

\section{EXPERIMENTAL}

\section{Chemicals and reagents}

PF573,228, dimethylsulfoxide (DMSO), 3-(4,5-dimethyl-2-thiazolyl)-2,5-diphenyltetrazolium-bromide (MTT) and Dulbecco's modified Eagle's medium (DMEM) were purchased from Sigma-Aldrich, USA. Fetal bovine serum (FBS) was supplied by the Scientific Group (SA), while penicillin-streptomycin was purchased from Whitehead Scientific (SA). PF573,228 was reconstituted in DMSO, aliquoted and stored at $-20{ }^{\circ} \mathrm{C}$. A final concentration of $0.1 \%$ DMSO was used as a control in all experiments.

\section{Cell culture}

Endothelioma (sEnd.2) cells, which were derived from mouse vascular tumors growing subcutaneously, were provided by Prof. M. S. Pepper (University of Pretoria, South Africa). The sEnd.2 cells were maintained in flasks (area $25 \mathrm{~cm}^{2}$ ) in a humidified atmosphere containing $5 \% \mathrm{CO}_{2}$ at $37^{\circ} \mathrm{C}$. The cells were cultured in DMEM, supplemented with $10 \%$ FBS and $1 \%$ penicillin-streptomycin.

\section{Cell growth assay}

The effects of PF573,228 on endothelioma cells were assessed by determining the percentage of viable cells using the 3-(4,5-dimethyl-2-thiazolyl)-2,5-diphenyltetrazolium-bromide (MTT) assay. Endothelioma cells were seeded in 96-well plates at a density of 5000 cells per well overnight, and then treated with PF573,228 (0-10 $\left.\mu \mathrm{mol} \mathrm{L}^{-1}\right)$ for 24 hours. The cells were rinsed with phosphate buffered saline (PBS) and $20 \mu \mathrm{L}$ MTT was added to each well. After 4 hours of incubation, MTT crystals were dissolved with addition of acidic isopropanol (100 $\mu \mathrm{L}$ per well). The absorbance was read at $570 \mathrm{~nm}$ on an ELx 800 Universal Microplate Reader (Bio-Tek instruments Inc, SA). 


\section{Hematoxylin and eosin staining}

Endothelioma cells were seeded on heat-sterilized cover slips in 6-well plates at a density of $3 \times 10^{5}$ cells per well overnight. The cells were treated with PF-573,228 $(0-10 \mu \mathrm{mol}$ $\mathrm{L}^{-1}$ ) over a period of 24 hours and then stained with hematoxylin and eosin (H\&E) using the previously described method (10). The cells were fixed in Bouin's fluid. After $30 \mathrm{~min}-$ utes of fixing, they were rinsed in $70 \%$ ethanol for a further 30 minutes, and then rinsed with water. The cells were immersed in Meyer's haemalum for 20 minutes, rinsed with water for two minutes, followed by $70 \%$ ethanol. The cells were incubated for two minutes in $1 \%$ eosin and then rinsed twice with increasing concentrations of ethanol (70, 96 and $100 \%)$. Xylol was used to rinse the cells twice before mounting them onto microscopic glass slides using resin. The slides were viewed with an Olympus BX63 light microscope (Wirsam Scientific, SA) and images were captured using the Olympus DP72 digital camera (Wirsam Scientific).

\section{Transmission electron microscopy}

The sEnd.2 cells were treated with 0-10 $\mu \mathrm{mol} \mathrm{L}^{-1} \mathrm{PF}-573,228$ for 24 hours and then processed for transmission electron microscopy (TEM) using a standard protocol as described previously (13). Mounted sections were then viewed using TEM (Apollo Scientific, SA).

\section{Caspase activity}

Endothelioma cells were seeded in 6-well plates at a density of $3 \times 10^{5}$ cells per well and allowed to attach overnight. The cells were treated with PF573,228 at the indicated doses for 24 hours. Caspase-3 activity was measured using a commercially available kit according to the manufacturer's instructions (BioVision, Mountain View, USA).

\section{Cell migration}

Cell migration was measured using xCELLigence Real Time Cell Analysis (RTCA) instrument, which measures the electrical impedance of migrating cells and records it as the cell index $(\mathrm{CI})$ value. The $\mathrm{CI}$ value is derived from the relative change in electrical impedance over time. Medium supplemented with $10 \mathrm{ng} \mathrm{L}^{-1}$ basic fibroblast growth factor (bFGF) was introduced to the bottom chambers of the cell invasion and migration (CIM) plates. Prior to the seeding of cells, $50 \mu \mathrm{L}$ of serum free medium was added to the top chamber of each CIM plate.

The plates were then allowed to equilibrate for 60 minutes at $37^{\circ} \mathrm{C}$ before a background measurement was taken using the RTCA instrument. Endothelioma cells were then added to the top chambers of the plates at a density of 6000 cells per well and treated with PF573,228 (0-10 $\left.\mu \mathrm{mol} \mathrm{L}^{-1}\right)$. Cell migration was monitored for 21 hours. Results are represented as the cell index (CI) without normalization.

\section{Aorta ring assay}

Aortas were harvested from 6-8 week old male Sprague-Dawley rats, cleaned by removing periaortic fibrofatty tissue and blood clots using scissors and fine forceps. The 
aortas were cut into 1-mm wide rings and transferred into Petri-dishes with fresh, serumfree, MCDB-131 medium. The rings were then embedded in fibrin gel in 24-well culture plates. The cultures were maintained in MCDB-131 medium supplemented with $0.3 \mathrm{mg}$ $\mathrm{mL}^{-1}$ amino caproic acid and $1 \%$ penicillin/streptomycin solution. The cultures were treated with PF573,228 (0-10 $\left.\mu \mathrm{mol} \mathrm{L}^{-1}\right)$ for 10 days. Medium and drugs were renewed every 2 days. Cultures were monitored for growth every second day using a Zeiss Axiovert microscope (Carl Zeiss, Germany) attached to a digital camera.

Ethical approval was obtained from the University of Pretoria's Animal Use and Care Committee.

\section{Antibody array studies}

The phosphorylation/activation status of eighteen signaling molecules was investigated using an intracellular signaling array kit (Cell Signaling, USA). The assay was undertaken according to the manufacturer's protocol. Glass slides were imaged using the Fluorchem E System (ProteinSimple, USA).

\section{Data analysis}

Statistical analysis was undertaken using the analysis of variance (ANOVA)-single factor model, followed by Tukey's ad hoc test, using the GraphPad Software version 4.00. The data are mean \pm SD unless stated otherwise, and differences were taken to be statistically significant at $p<0.05$.

\section{RESULTS AND DISCUSSION}

\section{Effects of PF573,228}

Cell growth. - The results showed that PF573,228 had little effect on the percentage of viable endothelioma cells at low concentrations $\left(0.1 \mu \mathrm{mol} \mathrm{L}^{-1}\right.$ and below) when compared to the controls (Fig. 1). At concentrations of $1 \mu \mathrm{mol} \mathrm{L}-1$ and above, the drug induced a significant decrease in cell growth $\left(p<0.05\right.$ ), with an $I C_{50}$ value of approximately $4.6 \mu \mathrm{mol} \mathrm{L}^{-1}$ (Fig. 1). Previous studies have shown that PF573,228 induced a significant inhibition of human umbilical vein endothelial cell (HUVEC) survival, although this was achieved at lower doses (14). Since the cells used in this study were not primary cells like HUVEC, but rather tumor cells, it is plausible that the cells could have been resistant. Indeed, previous studies have shown that protein kinase $\mathrm{B}(\mathrm{PKB})$, a downstream activator of FAK, was upregulated in endothelioma cells (10). This protein promotes cell survival (10). Inhibition of FAK phosphorylation could account for the observed decrease in cell growth, since the phosphorylation of FAK promotes cell survival and proliferation (14-16). To better understand the growth inhibitory effects of PF573,228 on these vascular tumor cells, the morphology of the cells was studied.

Cell morphology. - A monolayer of cells was observed in both the control and $1 \mu \mathrm{mol}$ $\mathrm{L}^{-1}$ PF573,228-treated cultures, although control cells appeared denser (Fig. 2). Also, control cells were in different phases of mitosis, while drug treated cells $\left(1 \mu \mathrm{mol} \mathrm{L}^{-1}\right)$ were mostly in interphase (Fig. 2). Thus, the decrease in the percentage of viable cells in cultures 


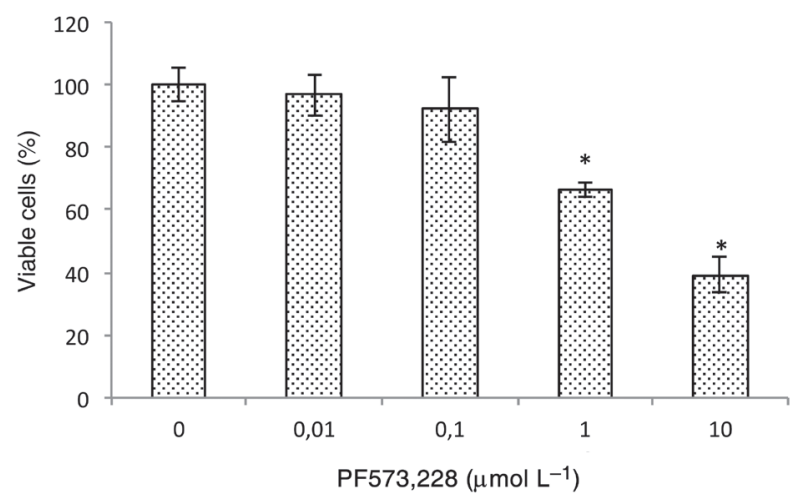

Fig. 1. Effect of PF573,228 on endothelioma cell growth. Data represent the mean of three wells \pm SD from three separate experiments $\left({ }^{*} p<0.05\right.$ compared to the control).

treated with $1 \mu \mathrm{mol} \mathrm{L}{ }^{-1}$ of the drug compared to the controls may have been largely due to reduced cell division rather than cell death. Indeed, H\&E images showed increased mitotic activity in control cultures and not in cultures treated with $1 \mu \mathrm{mol} \mathrm{L}-1$ PF573,228.

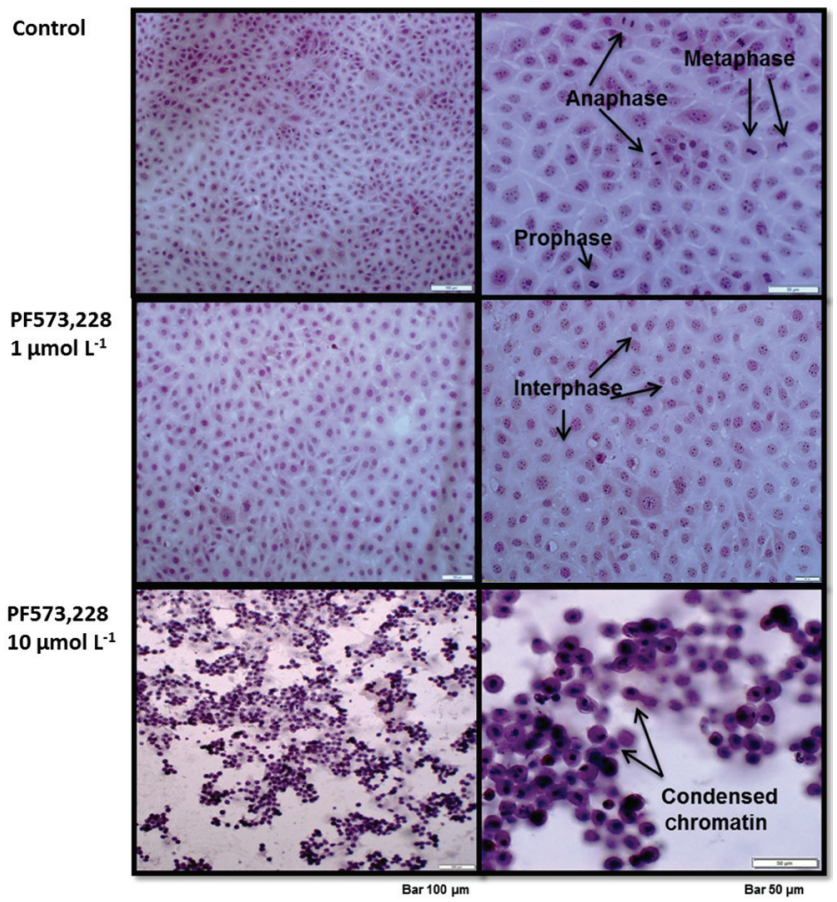

Fig. 2. Effect of PF573,228 on endothelioma cell morphology. Representative images of H\&E stained control cells as well as cells treated with 1 and $10 \mu \mathrm{mol} \mathrm{L}{ }^{-1}$ PF573,228. 
At $10 \mu \mathrm{mol} \mathrm{L}^{-1}$ of PF573,228, the cells seemed to have lost cell-cell contact. Since FAK is a protein that promotes cell-cell adhesion, it is not surprising that its inhibition disrupted cell-cell contact. Cells also appeared round in shape, with dark features that looked like condensed chromatin. To ascertain whether the observed dark features in H\&E stained cells reflected chromatin condensation, transmission electron microscopy was employed.

Micrographs from TEM studies revealed elongated cells with typical endothelial cell morphology in control and $1 \mu \mathrm{mol} \mathrm{L}{ }^{-1}$ PF573,228-treated cultures (Figs. 3a-d). Membranes of the cells in these cultures appeared smooth, without any attributes of blebbing (membrane blebbing is one of the early characteristics of apoptosis). Also, the nuclei of these cells had a normal appearance. In cultures treated with $10 \mu \mathrm{mol} \mathrm{L}-1$ PF573,228, condensed chromatin was observed (Figs. 3e,f). These findings confirmed H\&E observations. Furthermore, TEM micrographs showed cells with hypervacuolization (Figs. 3e,f). Both chromatin condensation and hypervacuolization are features of apoptotic cell death (17). Therefore, a caspase activity assay was employed to further determine potential apoptosis.

Caspase-3 activity. - At low doses of PF573,228, there was no effect on caspase-3 activity (Fig. 4). At $1 \mu \mathrm{mol} \mathrm{L}{ }^{-1}$, there was a marginal increase in caspase activity. A significant

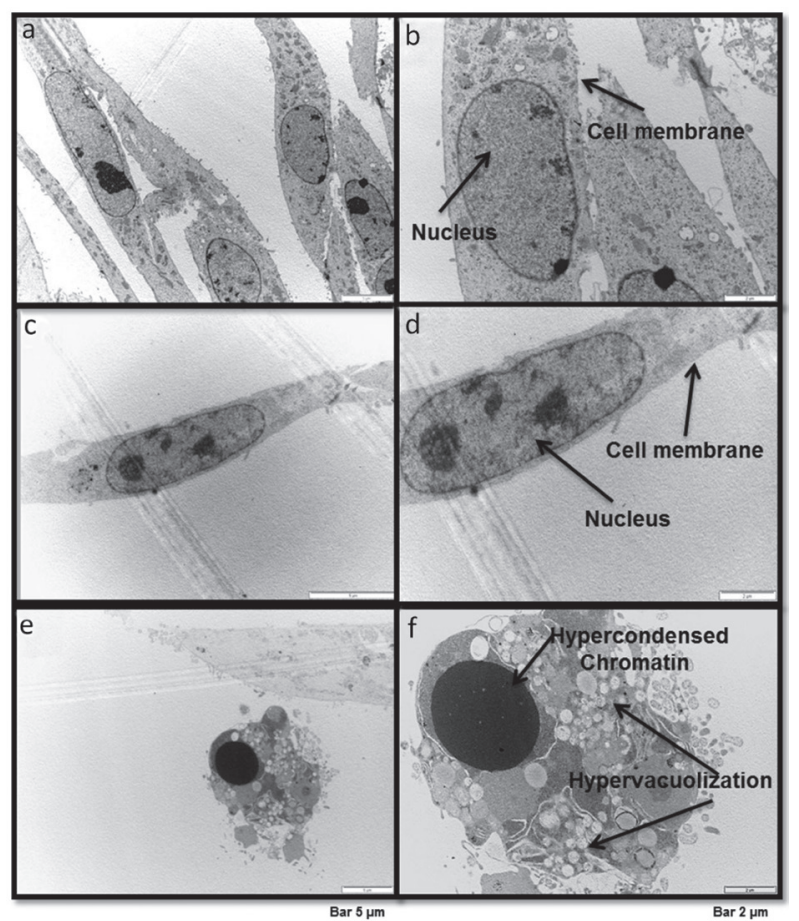

Fig. 3. PF573,228 induces apoptosis in endothelioma cells. Representative TEM micrographs of: a) and b) control endothelioma cells; c) and d) cells treated with $1 \mu \mathrm{mol} \mathrm{L}^{-1}$ and e) and f) $10 \mu \mathrm{mol} \mathrm{L}^{-1}$ PF573,228, respectively. 


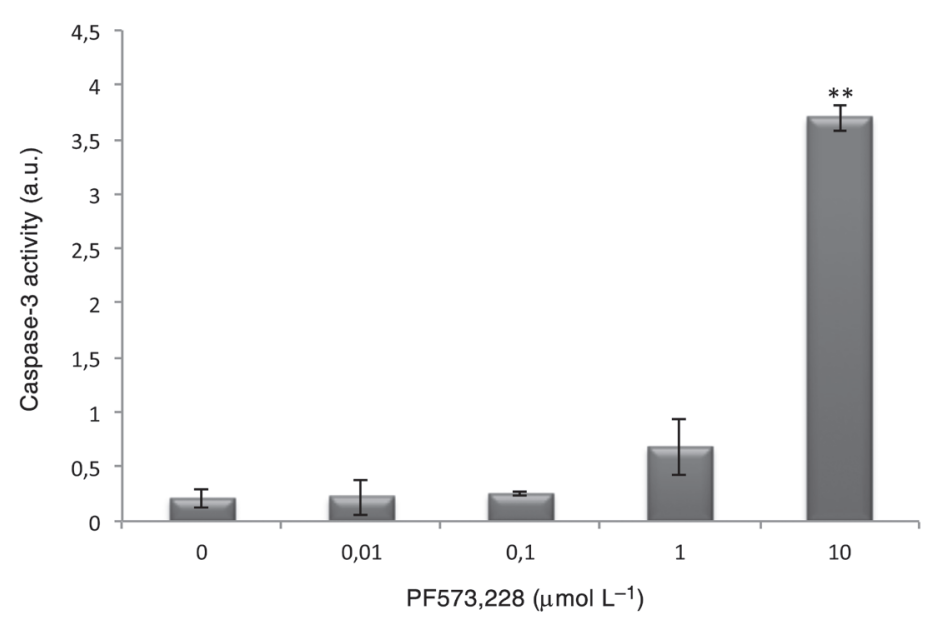

Fig. 4. Effect of PF573,228 on the activity of caspase- 3 in endothelioma cells. Values (in arbitrary units) are mean \pm SD from three experiments $\left({ }^{* *} p<0.001\right.$ compared to the control).

increase in the activation of caspase-3 $(p<0.001)$ was observed following the treatment of cells with $10 \mu \mathrm{mol} \mathrm{L}{ }^{-1}$ of the drug (Fig. 4). Since activated caspase-3 executes apoptosis, these observations indicate that the pronounced decrease in cell growth observed following the exposure of cells to $10 \mu \mathrm{mol} \mathrm{L}-1$ PF573,228 may be due, at least in part, to the induction of apoptosis by the drug.

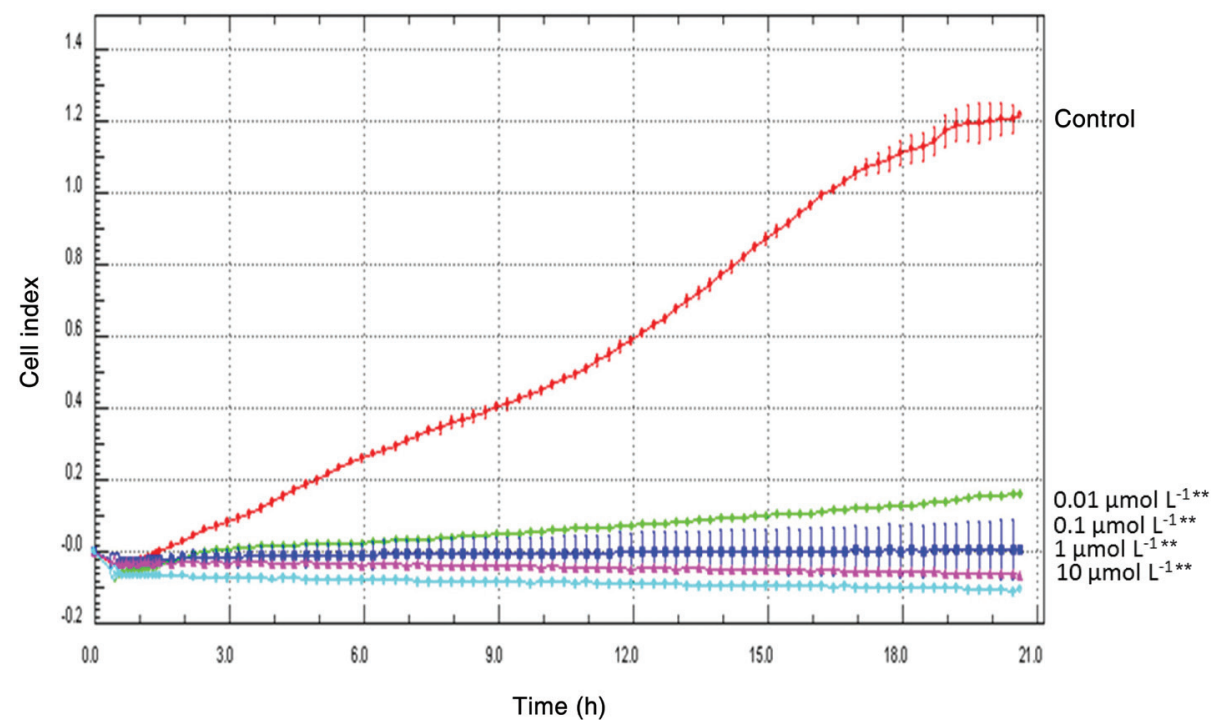

Fig. 5. PF573,228 inhibits endothelioma cell migration. Data are shown as the mean CI of four wells \pm SD. Three independent measurements were conducted $\left({ }^{* *} p<0.001\right.$ compared to the control). 

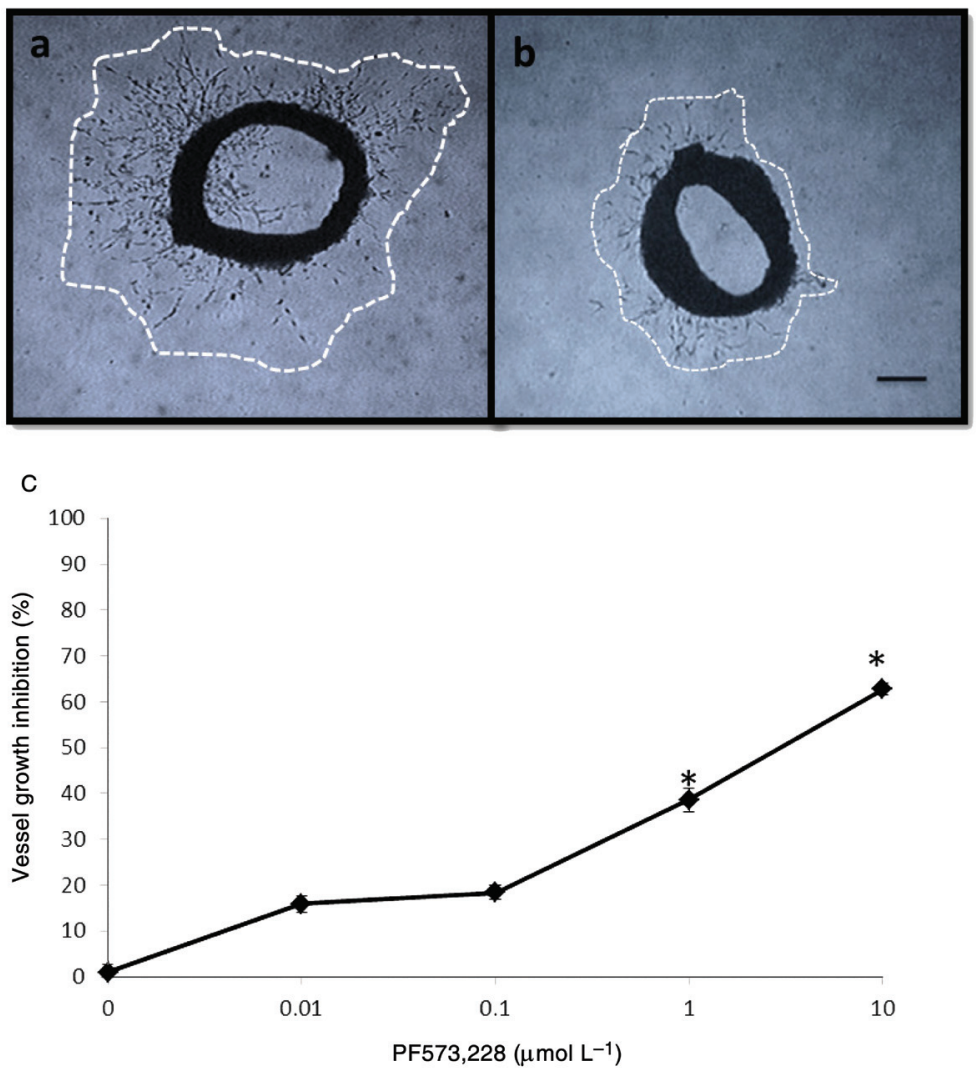

Fig. 6. PF573,228 reduces neovessel growth. Representative images of: a) control culture showing an aorta ring with microvessels emanating from its surface, $b$ ) an aorta ring treated with $10 \mu \mathrm{mol} \mathrm{L}^{-1}$ of PF573,228 showing a reduced area of neovessel growth (bar $250 \mu \mathrm{m})$. c) Graph showing the dosedependent effects of PF573,228 on microvessel growth in aorta ring cultures. Data represent the mean of three wells \pm SD. Three separate measurements were undertaken $\left({ }^{*} p<0.05\right.$ compared to the control).

Cell migration. - Focal adhesion kinase has previously been shown to modulate cell migration, particularly during angiogenesis (3). Therefore, the effects of blocking FAK with PF573,228 on cell migration were investigated using real time cell analysis. The results showed a significant decrease in the amount of cells that migrated from the top to the bottom chamber of the CIM plates following drug treatment when compared to the controls $(p<0.001)$, even at doses as low as $0.1 \mu \mathrm{mol} \mathrm{L}^{-1}$ (Fig. 5). The effects of PF573,228 on cell migration were dose-dependent, with an $I C_{50}$ of about $0.01 \mu \mathrm{mol} \mathrm{L}^{-1}$ (Fig. 5). The effects of PF573,228 on cell migration were dose-dependent, with an $I C_{50}$ of about $0.0128 \mu \mathrm{mol} \mathrm{L}^{-1}$ (Fig. 5). It has been reported that following the binding of the proangiogenic factor, vascular endothelial growth factor (VEGF), to the vascular endothelial growth factor receptor-2 (VEGFR-2), Src kinase, one of the downstream signaling molecules for VEGF, is recruited and activated, resulting in phosphorylation of $\operatorname{FAK}(18,19)$. This, in turn, leads to increased 

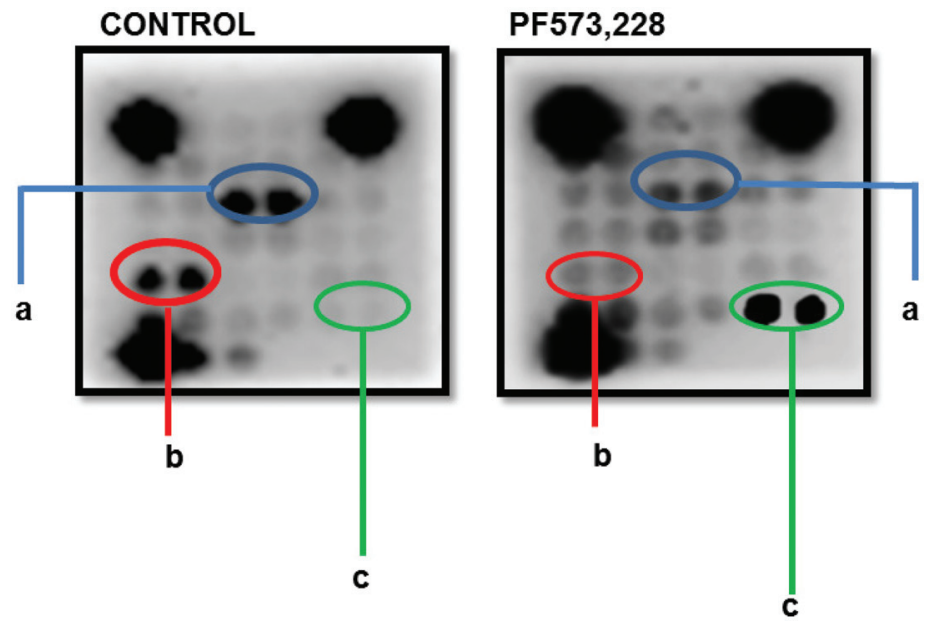

Fig. 7. Images captured by the Fluorchem E system showing the effects of PF573,228 on the phosphorylation/activation status of various intracellular signaling proteins: a) S6RP, b) PRAS40, c) cleaved caspase-3.

endothelial cell migration $(18,19)$. In addition, FAK-induced cell migration has been associated with the development of various neoplasms $(2,20)$. Thus, the blocking of FAK is a plausible target for therapeutic inhibition of cell motility, and perhaps of angiogenesis, since endothelial cell migration is crucial during the angiogenic process.

Angiogenesis. - Angiogenesis was evaluated using the aorta ring assay. In control cultures, aorta rings gave rise to neovessels; representative images are shown in Fig. 6a. The area of neovessel growth was reduced in cultures treated with PF573,228 (Fig. 6b). These observations were confirmed by quantitative analysis (Fig. 6c) which revealed that the drug induced a significant inhibition of angiogenesis at doses of 1 and $10 \mu \mathrm{mol} \mathrm{L}^{-1}(p<0.05)$. PF573,228 induced a dose-dependent inhibition of neovessel growth with an approx. $I C_{50}$ of $3.7 \mu \mathrm{mol} \mathrm{L}-1$. Focal adhesion kinase is required for tumor angiogenesis $(20,21)$. Therefore, FAK may be an important target in the abrogation of tumor angiogenesis, especially in the context of problematic vascular tumors such as infantile hemangiomas (IH) and hemangioendotheliomas.

Intracellular signaling proteins. - Phosphorylated proline-rich Akt-substrate 40 (PRAS40), a substrate of protein kinase B (PKB), was detected in control cells (Fig. 7). PF573,228 inhibited PRAS40 phosphorylation (Fig. 7). PRAS40 is phosphorylated by PKB $(22,23)$. In turn, phosphorylated PRAS40 promotes cell survival (22).

In the present study, phosphorylated S6 ribosomal protein (S6RP) was detected in control cells but not in the drug-treated cultures. These observations show that blocking FAK with PF573,228 inhibits S6RP phosphorylation. Focal adhesion kinase functions to phosphorylate S6RP $(24,25)$, thus activating this important effector of cell growth (25). Taken together, the drug blocks the phosphorylation of intracellular signaling molecules (PRAS40 and S6RP) that promote the growth of tumor cells. 
The current studies also showed that cleaved caspase-3 was detected in PF573,228treated cultures while the activated form of this protein was not detected in control cultures (Fig. 7). Proteolytic cleavage of inactive caspase-3 results in the formation of the activated form of this protease, which enables it to participate in the execution of apoptosis $(17,26)$. These array results on caspase- 3 correlate with the caspase-3 ELISA assay, which showed increased caspase- 3 activation in the drug-treated cells. Furthermore, microscopy observations showed morphological features of apoptosis in endothelioma cells treated with $10 \mu \mathrm{mol} \mathrm{L}-1$ PF573,228. Taken together, these observations indicate that PF573,228induced apoptosis may be caspase dependent.

Furthermore, PF573,228 may have a role in the elaboration of targeted therapeutic approaches for vascular lesions characterized by the overexpression of S6RP and PRAS40.

\section{CONCLUSIONS}

The data obtained from this study suggests that FAK blockade results in the inhibition of processes that are of essential benefit to the growth and progression of vascular tumors, namely, tumor cell growth, migration as well as angiogenesis. Endothelioma cell apoptosis was also induced, albeit at much higher doses.

Considering that growth-promoting proteins are overexpressed in control tumor cells, it is plausible that they might contribute to the development of tumors. Thus, S6RP and PRAS40 could be potential therapeutic targets. Furthermore, the correlation of FAK inhibition with decreased cell migration and angiogenesis at non-cytotoxic doses makes FAK an attractive target for combination approaches aimed at the treatment of vascular tumors.

Acknowledgements. - The author thanks Ms S. Nkadimeng (Angiogenesis Laboratory) and Ms L. du Plessis (Electron Microscopy Unit) for assistance with electron microscopy. This study was supported by the University of Pretoria and the National Research Foundation (Project no. 84430).

\section{REFERENCES}

1. J. K. Slack-Davis, K. H. Martin, R. W. Tilghman, M. Iwanicki, E. J. Ung, C. Autry, M. J. Luzzio, B. Cooper, J. C. Kath, W. G. Roberts and J. T. Parsons, Cellular characterization of a novel focal adhesion kinase inhibitor, J. Biol. Chem. 282 (2007) 14845-14852; DOI: 10.1074/jbc.M606695200.

2. M. J. van Nimwegen and B. van der Water, Focal adhesion kinase: A potential target in cancer therapy, Biochem. Pharmacol. 73 (2007) 597-609; DOI: 10.1016/j.bcp.2006.08.011.

3. J. D. Hood and D. A. Cheresh, Role of integrins in cell invasion and migration, Nat. Rev. Cancer 2 (2002) 91-100; DOI: 10.1038/nrc727.

4. T. Miyazaki, H. Kato, M. Nakajima, M. Sohda, Y. Fukai, N. Masuda, R. Manda, M. Fukuchi, K. Tsukada and H. Kuwano, FAK overexpression is correlated with tumour invasiveness and lymph node metastasis in oesophageal squamous cell carcinoma, Br. J. Cancer 89 (2003) 140-145; DOI: 10.1038/sj.bjc.6601050.

5. J. T. Parsons, J. Slack-Davis, R. Tilghman and W. G. Roberts, Focal adhesion kinase: Targeting adhesion signaling pathways for therapeutic intervention, Clin. Cancer Res. 14 (2008) 627-632; DOI: 10.1158/1078-0432.CCR-07-2220. 
6. J. M. Stiles, R. K. Rowntree, C. Amaya, D. Diaz, V. Kokta, D. C. Mitchell and A. B. Brad, Gene expression analysis reveals marked differences in the transcriptome of infantile hemangioma endothelial cells compared to normal dermal microvascular endothelial cells, Vasc. Cell 5 (2013) 1-12; DOI: $10.1186 / 2045-824 X-5-6$.

7. L. V. Owens, L. Xu, G. A. Dent, X. Yang, G. C. Sturge, R. J. Craven and W. G. Cance, Focal adhesion kinase as a marker of invasive potential in differentiated human thyroid cancer, Ann. Surg. Oncol. 3 (1996) 100-105; DOI: 10.1007/BF02409059.

8. D. D. Schlaepfer, C. R. Hauck and D. J. Sieg, Signaling through focal adhesion kinase, Prog. Biophys. Mol. Biol. 71 (1999) 435-478; DOI: 10.1016/S0079-6107(98)00052-2.

9. L. A. Cohen and J. L. Guan, Mechanisms of focal adhesion kinase regulation, Curr. Cancer Drug Tar. 5 (2005) 629-643; DOI: 10.2174/156800905774932798.

10. P. Mabeta and M. S. Pepper, Inhibition of hemangioma development in a syngeneic mouse model correlates with Bcl-2 suppression and the inhibition of Akt kinase activity, Angiogenesis 15 (2012) 131-139; DOI: 10.10007/s10456-011-9248-7.

11. H. P. Gerber, A. McMurtrey, J. Kowalski, M. Yan, B. A. Keyt, V. Dixit and N. Ferrara, Vascular endothelial growth factor regulates endothelial cell survival through the phosphatidylinositol 3'-kinase/Akt signal transduction pathway. Requirement for Flk-1/KDR activation, J. Biol. Chem. 273 (1998) 30336-30343; DOI: 10.1074/jbc.273.46.30336.

12. K. T. Sabapathy, M. S. Pepper, F. Kiefer, U. Möhle-Steinlein, F. Tacchini-Cottier, I. Fetka, G. Breier, W. Risau, P. Carmeliet, R. Montesano and E. F.Wagner, Polyoma middle T-induced vascular tumor formation: the role of the plasminogen activator/plasmin system, J. Cell Biol. 137 (1997) 953-963; DOI: $10.1083 /$ jcb.137.4.953.

13. P. Mabeta and M. S. Pepper, Altered expression of platelet factor 4 and basic fibroblast growth factor correlates with the inhibition of tumor growth in mice, Biomed. Pharmacol. 69 (2015) 186-190; DOI: 10.1016/j.biopha.2014.11.018.

14. M. A. Cabrita, L. M. Jones, J. L. Quizi, L. A. Sabourin, B. C. McKay and C. L. Addison, Focal adhesion kinase inhibitors are potent anti-angiogenic agents, Mol. Oncol. 5 (2011) 517-526; DOI: 10.1016/ jmolonc.2011.10.004.

15. S. Hiscox, P. Barnfather, E. Hayes, P. Bramble, J. Christensen, R. I. Nicholson and P. Barrett-Lee, Inhibition of focal adhesion kinase suppresses the adverse phenotype of endocrine-resistant breast cancer cells and improves endocrine response in endocrine-sensitive cells, Breast Cancer Res. Treat. 125 (2011) 659-669; DOI: 10.1007/s10549-010-0857-4.

16. P. W. Bryant, Q. Zheng and K. M. Pumiglia, Focal adhesion kinase is a phospho-regulated repressor of Rac and proliferation in human endothelial cells, Biol. Open 15 (2012) 723-730; DOI: 10.1242/ bio. 20121008 .

17. L. Portt, G. Norman, C. Clapp, M. Greenwood and M. T. Greenwood, Anti-apoptosis and cell survival: A review, Biochim. Biophys. Acta 1813 (2011) 238-259; DOI: 10.1016/j.bbamcr.2010.10.010.

18. X. Zhao and J. L. Guan, Focal adhesion kinase and its signaling pathways in cell migration and angiogenesis, Adv. Drug Deliver. Rev. 63 (2011) 610-615; DOI: 10.1016/j.addr.2010.11.001.

19. S. K. Mitra, D. A. Hanson and D. D. Schlaepfer. Focal adhesion kinase: in command and control of cell motility, Nat. Rev. Mol. Cell Biol. 6 (2005) 56-68; DOI: 10.1038/nrm1549.

20. B. Tavora, S. Batista, L. Reynolds, S. Jadeja, S. Robinson, V. Kostourou, I. Hart, M. Fruttiger, M. Parsons and K. M. Hodivala-Dilke, Endothelial FAK is required for tumour angiogenesis, EMBO Mol. Med. 2 (2010) 516-528; DOI: 10.1002/emmm.201000106.

21. L. H. Xu, X. Yang, C. A. Bradham, D. A. Brenner, J. A. S. Baldwin, R. J. Craven and W. G. Cance, The focal adhesion kinase suppresses transformation-associated, anchorage-independent apoptosis in human breast cancer cells, J. Biol. Chem. 275 (2000) 30597-30604; DOI: 10.1074/jbc. M910027199. 
22. C. Wiza, E. B. M. Nascimento and D. M. Ouwens, Role of PRAS40 in Akt and mTOR signaling in health and disease, Am. J. Physiol. Endocrinol. Metab. 302 (2012) E1453-E1460; DOI: 10.1152/ajpendo.00660.2011.

23. H. Wang, Q. Zhang, Q. Wen, Y. Zheng, L. Philip, H. Jiang, J. Lin and W. Zheng, Proline-rich Akt substrate of $40 \mathrm{kDa}$ (PRAS40): A novel downstream target of P13k/Akt signaling pathway, Cell Signal. 24 (2012) 17-24; DOI: 10.1016/j.cellsig.2011.08.010.

24. I. Ruvinsky, N. Sharon, T. Lerer, H. Cohen, M. Stolovich-Rain, T. Nir, Y. Dor, P. Zisman and O. Meyuhas, Ribosomal protein S6 phosphorylation is a determinant of cell size and glucose homeostasis, Genes Dev. 19 (2005) 2199-2211; DOI: 10.1101/gad.351605.

25. B. Gan, Y. Yoo and J. Guan, Association of focal adhesion kinase with tuberous sclerosis complex 2 in the regulation of S6 kinase activation and cell growth, J. Biol. Chem. 281 (2006) 37321-37329; DOI: 10.1074/jbc.M605241200.

26. A. Porras and C. Guerrero, Role of p38 $\alpha$ in apoptosis: Implication in cancer development and therapy, Atlas Genet. Cytogenet. Oncol. Haematol. 15 (2011) 316-326; DOI: 10.4267/2042/44993. 